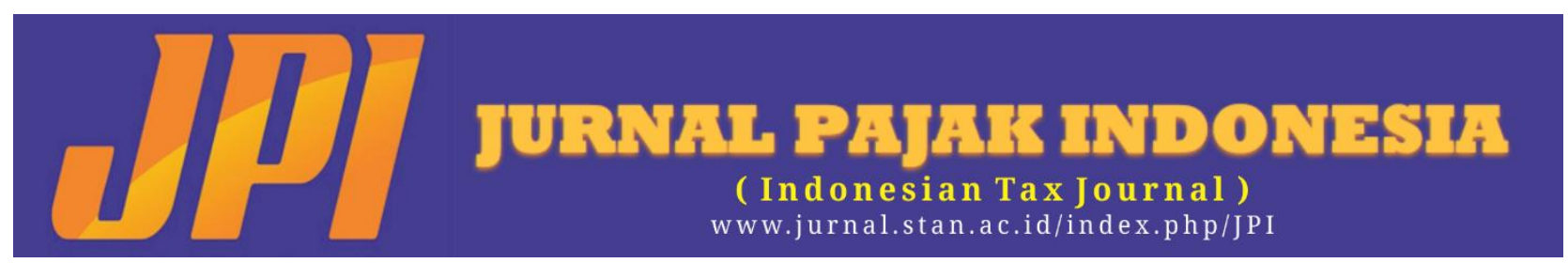

\title{
ANALISIS PERUMUSAN KEBIJAKAN MANDATORY DISCLOSURE RULES SEBAGAI ALTERNATIF DALAM MENGATASI PRAKTIK PENGHINDARAN PAJAK DI INDONESIA
}

\author{
Hari Utomo Triyanto \\ haregulus@gmail.com \\ Susi Zulvina \\ Politeknik Keuangan Negara STAN \\ susi_sadeq@yahoo.com
}

\section{INFORMASI ARTIKEL}

Diterima Pertama

19-10-2017

Dinyatakan Diterima

23-11-2017

KATA KUNCI: penghindaran pajak, perencanaan pajak agresif, MDR, kebijakan

KLASIFIKASI JEL:

H200; E600

\begin{abstract}
ABSTRAK
Tax avoidance is one of the most serious problems faced by countries in the world, especially for countries that make taxes as their main revenues. Tax avoidance practices will reduce the source of revenues in the country and become a potential for unhealthy competition between countries. OECD and G-20 countries have a plan to overcome tax avoidance in the whole world and to improve international tax regulations, one of which is that information transparency related to aggressive tax planning by Mandatory Disclosure Rules (MDR) policy. Indonesia is the association member but has not implemented that policy. As an OECD recommendation, the MDR policy form should be researched in order to be applicable in the taxation system in Indonesia.
\end{abstract}

\section{ABSTRAK}

Penghindaran pajak merupakan salah satu permasalahan serius yang dihadapi oleh negara- negara di dunia ini, khususnya bagi negara yang menjadikan pajak sebagai sumber utama pendapatan negara. Praktik penghindaran pajak akan mengurangi sumber penerimaan negara dalam negeri dan menjadi potensi persaingan yang tidak sehat antar negara. Organisation for Economic Development(OECD) bekerja sama dengan negara anggota G-20 berusaha mengatasi praktik penghindaran pajak di dunia dan ingin memperbaiki regulasi perpajakan internasional, salah satunya dengan cara tranparansi informasi terkait perencanaan pajak yang bersifat agresif dalam bentuk kebijakan Mandatory Disclosure Rules (MDR). Indonesia sebagai salah negara anggota sampai saat ini belum menerapkan kebijakan tersebut. Sebagai rekomendasi OECD, bentuk kebijakan MDR tersebut perlu diteliti agar dapat diterapkan dalam sistem perpajakan di Indonesia. 


\section{PENDAHULUAN}

\subsection{Latar Belakang}

Pajak sebagai sumber utama penerimaan negara menempatkan DJP pada posisi yang krusial karena pemerintah mengharapkan DJP mampu mencapai target penerimaan pajak yang telah ditetapkan setiap tahunnya. Realisasi penerimaan pajak pernah melampaui targetnya pada tahun 2008. Berdasarkan Laporan Tahunan DJP tahun 2008, DJP berhasil mencapai target penerimaan pajak sebesar $106,84 \%$. Namun pada tahun-tahun berikutnya hingga tahun anggaran 2017 ini, target penerimaan pajak belum pernah tercapai. Berdasarkan data pada Laporan Keuangan Pemerintah Pusat selama enam tahun terakhir, presentase realisasi penerimaan pajak tersebut semakin turun setiap tahunnya hingga presentase realisasi penerimaan pajak terendah terjadi pada tahun 2016 dengan 83,48\%.

Dalam self assessment system, pemerintah memberikan kepercayaan kepada masyarakat sebagai WP untuk menghitung, memperhitungkan, membayar dan melaporkan pajaknya sendiri. Pemerintah tentu mengharapkan kejujuran dan kesadaran WP untuk melaksanakan kewajiban perpajakannya agar dapat dilaksanakan dengan benar, lengkap, dan jelas. Namun, tingkat kepatuhan masyarakat dalam melaksanakan kewajiban perpajakannya masih kurang memuaskan. Berdasarkan Laporan Tahunan DJP Tahun 2015, rasio penyampaian SPT Tahunan PPh sebagai salah satu indikator kepatuhan pajak hanya mencapai $60,42 \%$.

Era globalisasi dan digitalisasi sistem teknologi informasi berkembang semakin pesat mendukung praktik penghindaran pajak, baik yang bersifat legal maupun ilegal. OECD menggunakan istilah Base Erosion and Profit Shifting (BEPS) sebagai bentuk penghindaran pajak. Arifin (2014) menyatakan bahwa praktik pengalihan keuntungan ke negara lain dengan tarif pajak yang rendah telah memberikan persepsi bahwa praktik BEPS telah mengakibatkan pemerintah telah kehilangan banyak penghasilannya yang bersumber dari penerimaan pajak perusahaan.

Praktik penghindaran pajak masih banyak terjadi di Indonesia walaupun pemerintah telah melakukan upaya untuk menyempurnakan peraturan pajak yang ada. Sugiarti (2015) menyatakan, berdasarkan hasil analisis data dari Direktorat Pemeriksaan dan Penagihan DJP, presentase jumlah perusahaan multinasional yang berkedudukan di Indonesia dan yang menyatakan rugi serta tidak menyetor pajak selama lima tahun pajak terakhir semakin meningkat setiap tahunnya. Jumlah koreksi pemeriksaan pajak karena praktik transfer pricing juga juga mengalami peningkatan $\mathrm{Hal}$ itu selaras dengan pernyataan Bambang Brodjonegoro sewaktu masih menjabat sebagai Menteri Keuangan bahwa ada hampir dua ribu perusahaan modal asing di Indonesia yang selama sepuluh tahun terakhir tidak membayar pajak karena selalu mengklaim dirinya rugi dan negara kehilangan hampir lima ratus triliun rupiah dalam kurun waktu tersebut (Antaranews, 2016).
OECD bekerja sama dengan negara- negara G-20 berupaya untuk mengatasi permasalahan BEPS secara komprehensif dengan merumuskan dan mengesahkan lima belas rencana perubahan regulasi perpajakan internasional yang dikenal dengan istilah Global Action Plan. Salah satu bagian dari rencana tersebut, yaitu Action 12 adalah require taxpayers to disclose their aggressive tax planning arrangements. Wajib pajak diharuskan untuk mengungkapkan perencanaan pajak mereka yang bersifat agresif menggunakan kebijakan yang disebut dengan istilah Mandatory Disclosure Rules (MDR). Kebijakan MDR bertujuan agar otoritas pajak memperoleh informasi lebih dini atas perencanaan pajak sehingga dapat memprioritaskan wilayah atau ruang lingkup berisiko tinggi.

Kebijakan MDR ini belum sepenuhnya berlaku dan dipraktikkan di Indonesia. Hingga saat ini, negara kita belum mempunyai peraturan atau kebijakan yang mewajibkan Wajib Pajak (WP) untuk mengungkapkan perencanaan pajak agresif yang selama ini telah diimplementasikan. Untuk itu perlu dianalisis bagaimana rumusan kebijakan MDR tersebut sehingga dapat membantu pemerintah atau DJP mengatasi masalah penghindaran pajak, meningkatkan kepatuhan WP, dan sebagai salah satu upaya memaksimalkan penerimaan pajak.

Berdasarkan latar belakang tersebut, rumusan masalah dalam penelitian ini adalah sebagai berikut:

a. Bagaimanakah rumusan kebijakan MDR yang ideal di Indonesia.

b. Bagaimanakah mekanisme kebijakan MDR sebagai alternatif dalam mengatasi praktik penghindaran pajak di Indonesia.

\subsection{Tujuan dan Manfaat Penelitian}

Tujuan dari penelitian ini adalah untuk mengetahui rumusan kebijakan MDR yang dapat diterapkan di Indonesia dan untuk mengetahui mekanisme kebijakan MDR sebagai alternatif kebijakan dalam mengatasi praktik penghindaran pajak di Indonesia. Hasil penelitian ini diharapkan dapat dimanfaatkan sebagai referensi atau masukan kepada DJP dalam perumusan atau perbaikan aturan perpajakan terkait. Hasil penelitian ini juga diharapkan dapat memberi pemahaman kepada praktisi, akademisi, atau pihak lain yang berkepentingan mengenai studi dan pertimbangan pengambilan keputusan terkait kebijakan MDR ini.

\section{KERANGKA TEORITIS}

\subsection{Konsep Penghindaran Pajak}

Dyreng $(2010,3)$ mendefinisikan penghindaran pajak secara luas mencakup segala sesuatu yang dapat mengurangi pajak perusahaan relatif terhadap pendapatan akuntansi sebelum pajak perusahaan tersebut. Definisi tax avoidance menurut Brown (2012, 1) adalah "arrangement of a transaction in order to obtain a taxadvantage, benefit, orreduction in a manner unintended by the tax law." Brown menyatakan bahwa penghindaran pajak dilaksanakan dengan tindakan yang tidak sesuai dengan apa yang 
dimaksudkan dalam peraturan atau hukum pajak. Tax avoidance atau penghindaran pajak adalah tindakan yang masih legal memanfaatkan celah-celah (loopholes) atau kelemahan-kelemahan yang ada pada aturan-aturan pajak dengan maksud untuk menghindari kewajiban perpajakan.

Ning Rahayu (2010, 64-65) mencoba membahas lima modus skema penghindaran pajak yaitu sebagai berikut:

a. Transfer Pricing, dengan merekayasa pembebanan harga transaksi antara perusahaan-perusahaan yang mempunyai hubungan istimewa dalam rangka meminimalkan beban pajak yang terutang secara keseluruhan atas grup perusahaan.

b. Pemanfaatan Tax Haven Country, yaitu negara-negara tertentu yang dengan sengaja memberikan fasilitas perpajakan baik berupa pengenaan pajak yang sangat rendah atau tidak dikenakan pajak sama sekali kepada WP negara lain agar penghasilan WP negara lain tersebut dialihkan ke negaranya.

c. Thin Capitalization, dengan membiayai cabang atau anak perusahaan berupa utang atau pinjaman yang melampaui batas kewajaran sehingga kewajiban anak perusahaan menjadi berkurang dan pengenaan pajak atas bunga akan lebih rendah jika induk perusaaan adalah perusahaan asing.

d. Treaty Shopping, yaitu ketika WPsuatu negara yang tidak memiliki tax treaty mendirikan perusahaan di negara yang memiliki tax treaty agar dikenakan pajak yang lebih rendah dan mendapat fasilitas perpajakan sebagaimana tercantum dalam tax treaty tersebut.

Controlled Foreign Corporation, dengan memanfaatkan perusahaanyang dikendalikan dan berkedudukan di luar negeri untuk menghindari pajak seperti mengalihkan penghasilan dan menunda pengumuman dividen.

\subsection{Konsep BEPS}

Wells dan Lowell dalam Arifin $(2014,2)$ menjelaskan bahwa Base Erosion and Profit Shifting (BEPS) adalah istilah yang sekarang ini digunakan oleh negara- negara anggota G-8, G-20, dan OECD untuk menjelaskan praktik usaha yang dilakukan oleh banyak perusahaan multinasional untuk memindahkan keuntungan usahanya melalui skema transfer pricing ke negara yang menerapkan tarif pajak rendah atau tarif nol. OECD dalam Sugiarti $(2015,20)$ mendefinisikan BEPS sebagai strategi perencanaan pajak (tax planning) yang memanfaatkan gap dan kelemahan- kelemahan yang terdapat dalam peraturan perundang-undangan perpajakan yang berlaku di dalam negeri untuk menghilangkan atau mengalihkan keuntungan tersebut ke negara lain yang memiliki tarif pajak atau bahkan bebas pajak, dengan tujuan akhir agar perusahaan tidak perlu membayar pajak atau pajak yang akan dibayar nilainya sangat kecil terhadap pendapatan perusahaan secara keseluruhan.

Arifin $(2014,2)$ menyatakan bahwa praktik BEPS dapat menciptakankompetisi yang tidak sehat diantara pelaku usaha, menciptakan ketidakadilan kepada WP untuk mematuhi kebijakan perpajakan yang sama, dan juga mengarah kepada alokasi sumber daya yang tidak efisien. OECD bekerja sama dengan negara-negara anggota G-20 untuk mengatasi permasalahan BEPS dengan melakukan reformasi perpajakan internasional. Mereka menyusun dan mengesahkan lima belas rencana untuk memerangi praktik BEPS yang dikenal dengan nama Action Plan on BEPS.

\subsection{Konsep MDR}

MDR merupakan bagian dari lima belas Action Plan on BEPS yang dirumuskan oleh OECD dan negara-negara anggota G- 20, tepatnya Action 12"Require tax payers to disclose their aggressive tax planning arrangements (OECD, 2013)." Tujuan utama dari MDR sebagaimana dinyatakan oleh OECD (2015, 18) adalah untuk menyediakan informasi lebih awal mengenai skema aggresive tax planning maupun abusive tax planning dan mengidentifikasi penasehat pajak (promoters) dan pengguna skema tersebut. Deteksi dini dari informasi yang relevan dan cepat dapat meningkatkan efektivitas otoritas pajak yang mendukung kepatuhan. Hasilnya identifikasi ini dapat membantu otoritas pajak untuk melakukan telaah dan menanggapi skema penghindaran pajak.

Elemen dasar dari MDR sebagaimana dijelaskan oleh $\operatorname{OECD}(2015,18-19)$ adalah sebagai berikut.

a. Who has to report, adalah tentang siapa yang akan melakukan pengungkapan.

b. What has to bereported, adalah tentang apa yang diungkapkan.

c. When information is reported, adalah tentang kapan pengungkapan tersebut dilakukan.

d. What other obligations (if any) should be placed on promoters and/or scheme users, adalah tentang bentuk pengungkapan agar seragam dengan negara lain. What are the consequences of non- compliance, adalah tentang sanksi jika pengungkapan tidak dilakukan.

e. What are the consequences of disclosure, adalah tentang tindak lanjut oleh otoritas pajak atas pengungkapan.

f. How to use the information collected, adalah tentang tindak lanjut oleh otoritas pajak atas informasi yang dikumpulkan.

\subsection{Teori Kebijakan Pajak}

Alink dan Kommer $(2011,40)$ menyatakan bahwa pajak mempengaruhi keputusan kehidupan. Oleh karena itu sistem perpajakan yang efisien dan kompetitif seharusnya meminimalkan penyimpangan atau distorsi yang timbul akibat sifat pajak yang memaksa, baik dalam pekerjaan, saving, dan investasi. 
Sistem perpajakan yang efisien dapat memadukan dengan tepat antara dasar pengenaan pajak (tax bases) dan tarif pajak yang dikenakan (tax rates). Untuk mewujudkan sistem pajak dengan struktur yang bagus dan untuk mencapai tujuan perpajakan di atas, diperlukan kebijakan sebagai salah satu instrumen dalam perpajakan. Alink dan Kommer (2011, 52-54) menjelaskan berbagai karakter kebijakan yang dapat digunakan dalam sistem pajak antara lain sebagai berikut:

a. Neutrality/efficiency, kebijakan tersebut dapat mendistorsi perilaku seminimal mungkin.

b. Low administration and compliance costs, biaya yang timbul baik dari otoritas pajak maupun WP dapat seminimal mungkin.

c. Flexibility, pajak dan sistem pajak dapat fleksibel menyesuaikan perubahan internal maupun eksternal.

d. Political responsibility (transparency), adanya kejelasan atau keterbukaan atas apa saja yang dikenakan, siapa yang dikenakan pajak, siapa yang menerima penghasilan.

e. Simplicity, pajak seharusnya dapat mudah dipahami oleh WP.

f. Fairness (or equity), pajak dapat menciptakan keadilan horizontal (perlakuan antar WP) dan keadilan vertikal (perlakuan yang konsisten kepada seorang WP).

g. Final incidence, pertimbangan yang matang oleh pembuat kebijakan terhadap tujuan akhir dampak suatu pajak.

h. Feasibility, pajak seharusnya layak dan dapat diimplementasikan.

i. Macroeconomic stability, pajak berperan dalam menstabilkankan kondisi ekonomi. Benefit principle, mendasarkan prinsip "membayar biaya atas jasa yang disediakan perintah."

j. Stability of revenue, sistem pajak menstabilkan penerimaan pajak yang cenderung fluktuatif atas kondisi ekonomi tertentu.

k. International compatibility, diperlukan peraturan dan atribusi pajak yang jelas sehingga dapat meningkatkan sumber daya pajak antar negara.

I. Non-discrimination principle, tidak ada perbedaan perlakuan perpajakan kepada WP baik di luar negeri maupun di dalam negeri.

m. Ability to pay, setiap WP seharusnya berkontribusi berdasarkan kemampuannya untuk membayar pajak.

n. Convenient timing, sistem pajak menyesuaikan waktu terbaik mengikuti kondisi WP untuk dikenakan pajak.

o. Timing, kecukupan persiapan waktu untuk mengimplementasikan suatu sistem pajak, baik dari WP maupun administrasi pajak.

\section{METODE PENELITIAN}

Jenis penelitian yang digunakan dalam penyusunan tulisan ini adalah penelitian kualitatif dengan metode non studi kasus dan menggunakan pendekatan analisis deskriptif. Objek penelitian ini ada dua.

Pertama, konsep dan praktik MDR yang diterapkan di negara-negara lain, yaitu Inggris, Amerika Serikat, Kanada, Irlandia, dan Portugal. Kedua, rumusan kebijakan MDR yang ideal di Indonesia yaitu mengenai subjek atau pelapor, objek pelaporan, waktu pelaporan, dan sanksi atas ketidakpatuhan pelaksanaan MDR.

Jenis data yang digunakan dalam penelitian ini adalah data primer dan data sekunder. Data primer, merupakan data yang berasal dari sumber pertama berupa hasil wawancara mendalam (indepth interview). Data primer diperoleh dari wawancara yang dilakukan kepada pihak yang mewakili atau terkait komponen kebijakan seperti pembuat kebijakan, fiskus, wajib pajak, konsultan pajak, praktisi pajak, dan kalangan akademisi. Data sekunder, merupakan data yang dikumpulkan dari sumber yang telah ada, berupa data dan informasi dari laporan, jurnal, buku, peraturan-peraturan, dan literatur-literatur lain yang terkait.

Metode pengolahan data yang digunakan menggunakan model analisis data Miles and Huberman. Pandangan Miles dan Huberman dalam Sugiyono (2016, 246) menyatakan bahwa aktivitas dalam analisis data kualitatif dilakukan secara interaktif dan berlangsung secara terus menerus sampai tuntas, sehingga datanya sudah jenuh. Tahapan pengolahan data diawali dengan reduksi data, penyajian data, dan pengambilan simpulan.Pengujian keabsahan data menggunakan metode triangulasi sumber.

\section{HASIL DAN PEMBAHASAN}

\subsection{Subjek Atau Pelapor Kebijakan MDR}

OECD merekomendasikan dua pilihan terkait siapa yang seharusnya melaksanakan kewajiban MDR ini. Pilihan pertama, pelapor kebijakan MDR adalah kedua pihak baik promotor maupun pengguna. Pilihan kedua, pelapor kebijakan MDR adalah salah satu antara promotor dan pengguna. Berdasarkan praktik kebijakan MDR yang telah dilaksanakan di beberapa negara, pelapor kebijakan tersebut juga dapat dibagi menjadi dua, yaitu keduanya promotor dan pengguna serta salah satu antara promotor dan pengguna.

Berdasarkan pendapat beberapa narasumber, pelaksana kewajiban MDR dapat dibagi menjadi tiga kelompok. Pendapat pertama adalah promotor yang lebih tepat melaksanakan kewajiban MDR. Promotor menjadi fokus pelapor MDR karena adanya pendapat bahwa penawaran atau supply skema dari promotor yang menciptakan permintaan atau demand oleh pengguna. Namun hal yang harus diperhatikan adalah dasar hukum untuk menjadikan promotor sebagai pelaksana MDR agar tidak bertabrakan dengan peraturan hukum masing-masing profesi, seperti 
konsultan, akuntan publik, bank, atau lembaga keuangan lainnya.

Pendapat kedua adalah WP yang lebih tepat melaksanakan kewajiban MDR. Ada pendapat narasumber yang menyatakan bahwa pada dasarnya promotor adalah WP dan MDR dapat menjaring promotor sebagai WP. UU KUP tidak membatasi WP untuk mengungkapkan data perpajakannya, namun perlu ditambahkan ketentuan bahwa WP harus mengungkapkan data terkait skema perencanaan pajak yang terlibat. WP merupakan pihak yang saat ini berinteraksi langsung dengan DJP, bukan promotor. Aspek efisiensi sumber daya perlu dipertimbangkan, baik dari pelapor maupun dari DJP.

Pendapat ketiga adalah baik promotor dan WP wajib melaksanakan MDR. Dengan mewajibkan kedua pihak untuk melaporkan skema perencanaan pajak, maka ada mekanisme crosscheck. Promotor bertanggung jawab atas supply skema yang dirancang, WP bertanggung jawab atas demand skema yang diimplementasikan dan memperoleh manfaat pajak.

Kelebihan dua pihak (promotor dan pengguna) yang melaksanakan kewajiban MDR adalah dapat memberikan efek jera lebih kuat, baik dari promotor maupun pengguna. Selain itu, pengungkapan yang dilakukan lebih luas cakupannya sehingga dapat mengurangi risiko pengungkapan yang tidak memadai serta informasi yang diperoleh dapat lebih akurat dan komprehensif. Namun pilihan ini akan menyerap sumber daya yang lebih besar, baik dari pihak pelapor maupun otoritas pajak.

\subsection{Objek Pelaporan Kebijakan MDR}

OECD memberikan dua pilihan terkait aturan ambang batas objek pelaporan kebijakan MDR. Pilihan pertama adalah pendekatan single-step, yaitu tidak menetapkan ambang batas atas skema yang akan dilaporkan. Pendekatan ini diadopsi oleh Amerika Serikat, dimana manfaat pajak domestik tidak diidentifikasikan sebagai penghindaran pajak. Konsekuensinya, kebijakan tersebut harus mendefinisikan dengan lebih terperinci tentang apa saja skema atau transaksi yang perlu dilaporkan, termasuk definisi material advisors sebagai pelapor. Pilihan kedua adalah pendekatan multiple-step, yaitu menggunakan ambang batas tertentu atas setiap transaksi untuk menyaring skema atau transaksi apa saja yang seharusnya dilaporkan. Beberapa negara seperti Inggris, Irlandia, Kanada, dan Portugal mengadopsi pendekatan ini yang diwujudkan dalam bentuk kategori- kategori tertentu atau hallmarks yang digunakan sebagai referensi skema.

Dalam penerapannya di beberapa negara, hallmarks biasanya terdiri atas dua kategori, yaitu generic hallmarks dan specific hallmarks.

a Generic hallmarks merupakan indikasi atau ciri khas yang bersifat umum atas skema yang diperkenalkan oleh promotor. Generic hallmarks juga digunakan untuk menangkap skema perencanaan pajak yang bersifat baru atau inovatif serta mudah untuk ditiru dan digunakan oleh WP. Generic hallmarks biasanya terdiri dari confidentiality hallmarks, premium fee hallmarks, contractual protection, dan standardized tax products.

b. Specific hallmarks merupakan indikasi atau ciri khas suatu skema yangbersifat lebih rinci dan menjadi perhatian otoritas pajak karena dianggap berisiko tinggi atau berpotensi adanya perencanaan pajak agresif. Specific hallmarks dirancang atas transaksi- transaksi tertentu sehingga dapat menangkap informasi yang lebih rinci dan relevan dibandingkan dengan general hallmarks. Contohnya antara lain loss scheme, lease arrangements scheme, employment scheme, dan income converting scheme.

Beberapa pendapat narasumber menyatakan bahwa Indonesia seharusnya dapat mengadopsi rekomendasi OECD terkait objek pelaporan kebijakan MDR, berupa generic hallmarks dan specific hallmarks. Kebijakan MDR seharusnya semakin membatasi ruang gerak WP untuk melakukan perencanaan pajak atau penghindaran pajak. Namun sebagai kebijakan yang tepat, harus diperhatikan juga aspek ekonomisnya. Alink dan Kommer (2011) menyatakan bahwa kebijakan pajak harus memperhatikan low administration and compliance costs, biaya yang timbul baik dari otoritas pajak maupun WP dapat seminimal mungkin. Kebijakan pajak juga harus memperhatikan aspek kesederhanaan (simplicity) dan kelayakan (feasibility).

Beberapa pendapat narasumber juga menyatakan bahwa objek pelaporan kebijakan MDR difokuskan kepada specific hallmarks, seperti transaksi rugi atau skema pemanfaatan tax haven country. Namun praktik tersebut harus memperhatikan aspek kerahasiaan, lintas yuridiksi negara, dan aspek ekonomi. Apa yang dilaporkan dalam MDR seharusnya mempertimbangkan informasi yang telah diperoleh dari instrumen kebijakan lain, seperti exchange of information, country by country reporting, dan transfer pricing document. Ketika ada informasi yang tidak dapat diperoleh dari kebijakan-kebijakan tersebut, MDR dapat melengkapinya.

\subsection{Jangka Waktu Pelaporan MDR}

Skema atau transaksi perencanaan pajak seharusnya segera dilaporkan kepada otoritas pajak mengingat tujuan utama dari MDR adalah untuk menyediakan informasi dini terkait skema penghindaran pajak. Semakin awal skema tersebut dilaporkan maka semakin besar pula kesempatan otoritas pajak untuk mengambil tindakan pencegahan. Selain itu, pelaporan yang semakin awal dapat mengurangi ketersediaan waktu pengguna untuk mengimplementasikan skema. Setiap negara memiliki aturan yang berbeda-beda terkait kapan pelaporan tersebut dilaksanakan. Periode pelaporan juga bervariasi mulai dari harian, bulanan, atau tahunan.

Pendapat narasumber pun juga berbeda- beda disesuaikan dengan pendapat mereka terkait subjek atau pelapor MDR. Sebagian besar narasumber berpendapat bahwa MDR dilaporkan bersamaan dengan 
laporan SPT Tahunan PPh sebagai lampiran SPT. Ada beberapa narasumber berpendapat bahwa pelaporan antara promotor dan WP dibedakan untuk menyesuaikan kebijakan MDR dengan tujuannya. Promotor seharusnya melaporkan MDR lebih awal untuk perolehan informasi sedini mungkin. Sedangkan WP melporkan MDR bersamaan dengan pelaporan SPT Tahunan PPh untuk menghemat biaya.

Promotor lebih disarankan untuk melaporkan sejak skema tersebut tersedia untuk diimplementasikan. Selain untuk mendapatkan informasi yang lebih awal, hal tersebut dapat mencegah skema tersebut diperkenalkan bahkan diimplementasikan ke lebih banyak pengguna. Untuk WP, jangka waktu pelaporan seharusnya sesingkat mungkin dihitung sejak skema diimplementasikan sehingga otoritas pajak dapat segera memberikan tanggapan dan mengambil tindakan korektif. Alink dan Kommer (2011) menyatakan bahwa pemerintah sebagai pembuat kebijakan harus mempertimbangkan dengan matang kebijakan MDR terhadap tujuan akhir dampak terhadap negara, yaitu kepatuhan yang tinggi dan pencapaian target penerimaan.

\subsection{Sanksi Ketidakpatuhan Pelaksanaan MDR}

OECD menyarankan bahwa sanksi atas ketidakpatuhan ini lebih disasarkan kepada promotor daripada WP. OECD berpendapat bahwa promotor lebih tahu dampak skema atau transaksi terhadap manfaat pajak, termasuk risiko-risiko yang akan timbul. Selain itu, efek jera yang ditimbulkan akan lebih kuat sehingga promotor dapat lebih berhati-hat ketika memperkenalkan skema kepada WP. Berdasarkan penerapan MDR di negara-negara lain, sanksi atas ketidakpatuhan pelaporan MDR bervariasi dengan mempertimbangan jenis pelapor, objek pelaporan, atau materialitas pelaporan MDR tersebut. Hampir semua negara pelaksana kebijakan MDR menerapkan sanksi moneter berupa denda.

Sanksi dapat didasarkan pada ketidakpatuhan tata cara, sama halnya dengan ketidakpatuhan penyampaian SPT. Sanksi lebih cenderung berbentuk sanksi administratif bukan sanksi pidana karena MDR hanya terbatas pada perencanaan pajak agresif bukan penggelapan pajak. Namun karena keterbatasan bentuk MDR sebagai peraturan pelaksana UU KUP, maka sanksi MDR disesuaikan berdasarkan UU KUP, sama halnya dokumen kesepakatan harga transfer. Beberapa narasumber sepakat bahwa sanksi MDR ini disesuaikan berdasarkan sanksi atas ketidakpatuhan penyampaian SPT Tahunan. Namun ada juga yang berpendapat bahwa sanksi atas ketidakpatuhan MDR seharusnya eksplisit diatur sendiri dan tidak disertakan dengan pasal atau ketentuan lain seperti ketentuan penyampaian SPT.

Hal yang harus diperhatikan dalam menetapkan sanksi atas ketidakpatuhan ini adalah memberikan tekanan dan efek jera kepada promotor atau WP sehingga dapat meningkatkan kepatuhan terhadap peraturan. Alink dan Kommer (2011) menyatakan bahwa kebijakan pajak dapat mendistorsi perilaku seminimal mungkin (neutrality/efficiency). Penetapan sanksi ini, terutama sanksi moneter, bukan sematamata untuk tujuan penerimaan melainkan untuk terciptanya kepatuhan pelaksanaan MDR sehingga praktik BEPS dapat diminimalkan. Sanksi yang diterapkan juga dapat memberikan keadilan bagi WP yang patuh dan yang tidak patuh.

\subsection{Kebijakan MDR Sebagai Alternatif Peraturan Dalam Mengatasi Praktik Penghindaran Pajak di Indonesia}

Berdasarkan analisis beberapa peraturan perpajakan dalam rangka mengatasi praktik penghindaran pajak, sebenarnya DJP telah memiliki banyak instrumen kebijakan untuk mengungkapkan transparansi data atau informasi WP atau pihak lainnya untuk kepentingan perpajakan sehingga informasi yang diperoleh bersifat tepat waktu, komprehensif, dan relevan. Informasi- informasi ini dapat digunakan DJP untuk menganalisis dan mengevaluasi risikorisiko apa saja yang masih belum dicakup peraturan yang ada. Selain itu, informasi yang diperoleh dan menjadi evaluasi yang digunakan untuk perumusan kebijakan MDR, dengan melihat skema atau transaksi mana saja yang belum tersentuh aturan, siapa saja yang dapat dipertimbangkan menjadi promotor, kapan MDR seharusnya dilaporkan, atau rekomendasi sanksi yang memberikan efek jera bagi WP.

Otoritas pajak Indonesia memiliki banyak instrumen untuk membatasi ruang gerak WP dengan menyaring informasi seperti dokumen transfer pricing, Country by Country Reporting, automatic Exchange of Information, dan keterbukaan informasi keuangan. Dari evaluasi informasi yang diperoleh tersebut, kebutuhan masih diperlukan dapat dilengkapi melalui MDR. Selain itu, evaluasi dari semua kebijakan yang ada sebenarnya dapat menentukan apakah MDR tersebut memang diperlukan. DJP juga seharusnya menambah kapasitas sumber daya manusia DJP harus lebih ditingkatkan dan lebih kreatif dalam menganalisa informasi yang ada.

Semua narasumber sepakat bahwa kebijakan MDR dapat dijadikan sebagai alternatif atau pelengkap dari kebijakan pajak yang selam ini digunakan untuk mengatasi praktik penghindaran pajak. Peraturan perpajakan yang ada telah mencakup wilayah untuk mengatasi praktik penghindaran pajak. Namun peraturan tersebut terlalu umum dan belum bisa 
menyelesaikan atau menurunkan risiko kerugian penerimaan pajak. Kebijakan MDR tidak hanya melengkapi peraturan yang sudah ada tetapi juga diperlukan untuk menyaring informasi atas kebenaran suatu transaksi dilihat dari aspek legalitas dan aspek substansinya. Pemerintah seharusnya membuat general anti avoidance rules yang mencakup seluruh praktik penghindaran pajak dari pada membuat specific anti avoidance rules. MDR dapat menjadi bagian dari general anti avoidance rules tersebut.

Kebijakan MDR dapat digunakan sebagai sarana introspeksi bagi DJP, bukan alat untuk mengejar WP. Quick responses atas informasi yang diperoleh dari MDR diharapkan dapat menutup celah-celah hukum yang saat ini dimanfaatkan WP untuk meminimalkan pajak mereka. MDR dapat memberikan informasi sebanyak- banyaknya atas skema perencanaan pajak agresif yang menambah basis data DJP. Selanjutnya DJP dapat mengklasifikasikan dan membuat penilaian risiko sebelum dilakukan perbaikan kebijakan yang telah ada.

Kebijakan MDR sebaiknya harus dirumuskan secara hati-hati dan dipertimbangkan dengan matang agar tujuannya untuk memperoleh informasi dini dan memberikan quick responses dapat tercapai. Kebijakan harus disusun dengan jelas dan sederhana sehingga mudah dipahami oleh WP maupun promotor sehingga tujuan untuk memberikan efek jera dan kepatuhan perpajakan dapat tercapai. Kebijakan MDR juga harus mempertimbangkan compliance costs dan administration cost yang timbul dapat diminimalkan.

Informasi yang diperoleh DJP dimanfaatkan sedemikian sehingga memberikan kepastian hukum bagi WP dan menciptakan rasa keadilan. DJP juga harus mempertimbangkan aturan-aturan yang sudah ada sehingga kebijakan MDR dapat menyesuaikan dengan jelas posisinya sebagai alternatif atau suplemen aturan yang sudah ada. Hal yang diperlukan adalah kesiapan baik dari WP, promotor, maupun DJP dalam mempersiapkan dan mengimplementasikan kebijakan MDR sebagai salah satu instrumen untuk meminimalkan praktik BEPS dapat tercapai.

\section{KESIMPULAN}

\subsection{Simpulan}

Rumusan kebijakan MDR yang ideal untuk diterapkankan di Indonesia adalah sebagai berikut:

a Subjek atau pelapor kebijakan MDR dilaksanakan oleh baik promotor maupun WP. Kelebihannya adalah informasi yang diperoleh DJP lebih lengkap dan kompleks, dapat dilakukan mekanisme crosscheck antara promotor sebagai pembuat skema dan WP sebagai pengguna skema. Compliance cost dan administrative cost yang timbul akan besar. Namun jika manfaat yang diperoleh lebih besar dan kebijakan tersebut memberikan kepastian hukum dan menciptakan rasa keadilan bagi WP, maka pilihan tersebut dapat diterapkan.Objek pelaporan dalam kebijakan MDR sesuai dengan rekomendasi OECD berupa generic hallmarks dan specific hallmarks, yang difokuskan pada transaksi spesifik dengan mempertimbangkan hasil evaluasi informasi yang diperoleh dari peraturan-peraturan yang sudah ada sehingga cakupan objek pelaporannya tidak terlalu luas tetapi dapat menyasar pada informasi yang belum dijaring oleh peraturan-peraturan yang sudah ada.

b. Waktu pelaporan kebijakan MDR dibedakan berdasarkan jenis pelaporannya. Hal yang perlu dipertimbangkan adalah pelaporan yang sesegera mungkin, memberikan keadilan bagi pelapor, memudahkan pelaporan, dan aspek efisiensi. Untuk promotor, pelaporan paling lambat pada bulan berikutnya setelah skema siap diimplementasikan dan disampaikan bersamaan dengan pelaporan SPT Masa. Bagi WP, pelaporan paling lambat pada tahun pajak berikutnya setelah skema diimplementasikan sebagai lampiran SPT Tahunan.

c. Sanksi atas ketidakpatuhan pelaporan MDR dapat berupa sanksi administrasi berupa denda yang didasarkan pada ketentuan UU KUP dengan tujuan untuk memberikan efek jera dan meningkatkan kepatuhan. Sanksi pidana tidak diperlukan karena MDR hanya berkaitan dengan perencanaan pajak agresif dan tidak kepada wilayah penggelapan pajak (tax evasion).

Dalam penerapannya, kebijakan MDR dapat digunakan sebagai alternatif kebijakan atau peraturan untuk mengatasi praktik penghindaran pajak di Indonesia. Kebijakan MDR dapat difokuskan pada praktik pemanfaatan tax haven country karena pada praktik tersebut belum ada peraturan pelaksana yang secara ekplisit mengaturnya sehingga praktik tersebut marak terjadi di Indonesia. Peraturan yang digunakan untuk mengatasi praktik penghindaran pajak lainnya sudah ada laporan terkait pengungkapan informasi dari WP. Informasi dari MDR dapat dimanfaatkan oleh DJP dengan beberapa tindakan seperti pengklasifikasian skema, penilaian risiko, perbaikan kebijakan atau peraturan perundang-undangan, dan pertukaran data perpajakan secara internasional.

\subsection{Saran}

DJP dan Kementerian Keuangan sebaiknya dapat merumuskan kebijakan MDR dengan rinci dan hati-hati karena ada banyak hal baru yang diterapkan dalam 
kebijakan MDR ini. Keterlibatan promotor dan WP dalam penerapan MDR sebaiknya mempertimbangkan aspek kerahasiaan data, keterlibatan cross border transactions, dan aspek efisiensi. DJP harus mempersiapkan sumber daya dengan matang, baik sistem informasi, sumber daya manusia, anggaran, prosedur, maupun teknologi karena kebijakan MDR membutuhkan quick responses agar dapat mencapai tujuannya.

Kebijakan MDR seharusnya dibuat sederhana sehingga tidak menambah beban WP dan kompleksitas pajak tidak mengganggu aktivitas investasi dan ekonomi Indonesia. Kebijakan MDR seharusnya dapat memanfaatkan momen perubahan UU KUP dan UU PPh yang saat ini sedang dibahas oleh pemerintah dan legislative/ DPR sehingga ada landasan hukum yang kuat dan sanksi yang tepat dalam untuk menerapkan kebijakan MDR di masa datang.

Penulis menyadari bahwa jumlah narasumber penelitian masih terbatas. Kebijakan MDR sebgai bagian dari rekomendasi OECD masih cukup awam di kalangan umum. Sehingga untuk perbaikan penelitian selanjutnya, peneliti sebaiknya mempertimbangkan jumlah narasumber wawancara dan studi pustaka yang digunakan dapat ditambah sehingga dapat menghasilkan informasi yang relevan dan lengkap.

\section{DAFTAR PUSTAKA}

Alink, Matthijs dan Victor Van Kommer. 2011. Handbook on Tax Administration. Amsterdam: IBFD.

Allingham, M.G. dan A. Sandmo. 1972. Income Tax Evasion: A theoritical Analysis. Journal of Public Economics, 1: 323-338.

Arifin, Nanang Zainal. 2014. BEPS Dalam Kerangka Kerja Sama G20 Dan Implementasinya Kepada Indonesia. Badan Kebijakan Fiskal

Desai, M. A., \& Dharmapala, D. 2006. Corporate Tax Avoidance And High-Powered Incentives. Journal of Financial Economics, 79(1), 145-179. http://doi.org/10.1016/j.jfineco.2005.02.002.

Badan Pemeriksa Keuangan Republik Indonesia. 2012. Laporan Hasil Pemeriksaan BPK RI Atas Laporan Keuangan Pemerintah Pusat Tahun 2011. Jakarta: BPK RI.

Badan Pemeriksa Keuangan Republik Indonesia. 2017. Laporan Hasil Pemeriksaan BPK RI Atas Laporan Keuangan Pemerintah Pusat Tahun 2016. Jakarta: BPK RI.

Brown, K. B. 2012. A Comparative Look at Regulation of Corporate Tax Avoidance. New York: Springer.

Camara, Francisco de Sousa da, et al. 2008. Portugal Enacts New Discloure Obligation to Fight Abusive Tax Planning. Worldwide Tax Daily as: 2008 WTD 40-7

Darussalam, dan Danny Septriadi. 2009. Tax Avoidance, Tax Evasion, dan Anti Avoidance Rule. Danny Darussalam Tax Center. http://www.ortax.org.
Darussalam, dan Ganda C. Tobing. 2014. Rencana Aksi Based Erosion Profit Shifting dan Dampaknya Terhadap Peraturan Pajak di Indonesia. International Taxation Series. Danny Darussalam Tax Center. http://www.ddtc.co.id/en/publication/

Devereux, Michael P., et al. 2012. The Disclosure Of Tax Avoidance Schemes Regime. Oxford University Centre for Business Taxation.

Direktorat Jenderal Pajak. 2014. Perpajakan Internasional. Jakarta: Direktorat Jenderal Pajak.

Direktorat Jenderal Pajak. 2016. Laporan Tahunan DJP Tahun 2015. Jakarta: Direktorat Jenderal Pajak.

Dyreng, Scott D., et al. The Effects of Executives on Corporate Tax Avoidance. The Accounting Review, vol. 85, no. 4, 2010, pp. 1163-1189. www.jstor.org/stable/20744155.

Hanlon, Michelle, dan Shane Heitzman. 2010. A Review of Tax Research. Elsier Database. http://papers.ssrn.com/sol3/papers.cfm?abstr act_id=1476561.

HM Revenue and Custom (HMRC). 2004. Guidance Disclosure Of Tax Avoidance Schemes (DOTAS). HMRC

Hoopes, J. L., D. Mescall, J. A. Pittman. 2012. Do IRS Audits Deter Corporate Tax Avoidance?. The Accounting Review, 87 (5): 1603-1639

Huberman, Michael A \& Miles, Mathew B. Penerjemah Tjetjep Rohendi. 2009. Analisis Data Kualitatif Buku Sumber Tentang Metode-Metode Baru. Jakarta: UI Press.

Irawan, Prasetya. 2006. Penelitian Kualitatif dan Kuantitatif Untuk IImu-IImu Sosial. Jakarta: DIS FISIP UI

Kholbadalov, Utkir. 2012. The Relationship Of Corporate Tax Avoidance, Cost Of Debt, And Institutional Ownership: Evidence From Malaysia. Atlantic Review of Economics, 2nd Volume 2012.

Koek, N.G.P.M. 2014. Does Disclosure of Tax Avoidance Schemes Reduce Corporate Tax Avoidance?. Tilburg University.

Larin, Gilles. 2013. Some Thoughts on Disclosure Rule in Canada: A Peek Into The Future. Canadian Tax Journal (2013) 61 (SUPP), 209-220.

Mills, L. 1998. Book-Tax Differences and Internal Revenue Service Adjustments. Journal of Accounting Research, 36 (2): 343-356.

OECD. 2011. Tackling Aggressive Tax Planning Through Improved Transparency and Disclosure. OECD Publishing.

OECD. 2013. Addressing Base Erosion and Profit Shifting. OECD Publishing. http://dx.doi.org/10.1787/9789264192744-en

OECD. 2013. Action Plan on Base Erosion and Profit Shifting. OECD Publishing. http://dx.doi.org/10.1787/9789264202719-en

OECD. 2013. Co-operative Compliance: A Framework: From Enhanced Relationship to Co-operative Compliance. OECD Publishing. http://dx.doi.org/10.1787/9789264192744-en 
OECD. 2015. Mandatory Disclosure Rules, Action 122015 Final Report, OECD/G20 Base Erosion and Profit Shifting Project. Paris: OECD Publishing. http://dx.doi.org/10.1787/9789264241442-en

Rahayu, Ning. 2008. Praktik Penghindaran Pajak (Tax Avoidance) Pada Foreign Direct Investment Yang Berbentuk Subsidiary Company (PT. PMA) di Indonesia (Suatu Kajian Tentang Kebijakan). Depok: Universitas Indonesia.

Rahayu, Ning. 2010. Evaluasi Regulasi Atas Praktik Penghindaran Pajak Penanaman Modal Asing. Jurnal Akuntansi dan Keuangan Indonesia, Volume 7 No. 1, hal.61-78.

Slamet, Indrayagus. 2007. Abuse of Transfer Pricing melalui Tax Haven Countries. InsideTax Magazine Edisi pertama. Jakarta: DDTC

Suandy, Erly. 2008. Perencanaan Pajak. Edisi 4. Jakarta: Salemba Empat.

Sugiarti, Pratiwi Eka. 2015. Analisis Anti Avoidance Rules Dalam Mengatasi Praktik Base Erosion and Profit Shifting. Politeknik Keuangan Negara STAN

Sugiyono. (2016). Metode Penelitian Kuantitatif, Kualitatif dan $R$ \& $D$. Bandung: Alfabeta.

Wells, Bret and Lowell, Cym. Tax Base Erosion: Reformation of Section 482's Arm's Length Standard (August 15, 2013). 15 Florida Tax Review 737 (2014); U of Houston Law Center No. 2014-A-7. Available at SSRN: https://ssrn.com/abstract $=2310882$ or http://dx.doi.org/10.2139/ssrn.2310882

\section{Peraturan perundang-undangan}

Undang-Undang Republik Indonesia Nomor 36 Tahun 2008 Tentang Perubahan Keempat atas Undang-undang Nomor 7 Tahun 1983 tentang Pajak Penghasilan

Undang-Undang Republik Indonesia Nomor 16 Tahun 2009 Tentang Penetapan Peraturan Pemerintah Pengganti Undang-Undang Nomor 5 Tahun 2008 Tentang Perubahan Keempat Atas Undang Undang Nomor 6 Tahun 1983 Tentang Ketentuan Umum Dan Tata Cara Perpajakan Menjadi Undang-Undang

Peraturan Pemerintah Pengganti Undang-Undang Republik Indonesia Nomor 1 Tahun 2017 Tentang Akses Informasi Keuangan Untuk Kepentingan Perpajakan

Peraturan Menteri Keuangan Republik Indonesia Nomor 256/PMK.03/2008 tentang Penetapan Saat Diperolehnya Dividen Oleh WP Dalam Negeri Atas Penyertaan Modal Pada Badan Usaha di Luar Negeri Selain Badan Usaha yang Menjual Sahamnya di Bursa Efek

Peraturan Menteri Keuangan Republik Indonesia Nomor 169/PMK.010/2015 tentang Penentuan Besarnya Perbandingan Antara Utang dan Modal Perusahaan Untuk Keperluan Pengenaan Pajak Penghasilan
Peraturan Menteri Keuangan Republik Indonesia Nomor 235/PMK.03/2016 Tentang Perubahan Atas Peraturan Menteri Keuangan Nomor 87/PMK.03/2013 Tentang Tata Cara Permintaan Keterangan Atau Bukti Dari PihakPihak Yang Terikat Oleh Kewajiban Merahasiakan

Peraturan Menteri Keuangan Republik Indonesia Nomor 213/PMK.03/2016 tentang Jenis Dokumen dan/ atau Informasi Tambahan yang Wajib Disimpan oleh WP yang Melakukan Transaksi dengan Para Pihak yang Mempunyai Hubungan Istimewa, dan Tata Cara Pengelolaannya

Peraturan Menteri Keuangan Republik Indonesia Nomor 39/PMK.03/2017 Tentang Tata Cara Pertukaran Informasi Berdasarkan Perjanjian Internasional

Peraturan Menteri Keuangan Republik Indonesia Nomor 70/PMK.03/2017 Tentang Petunjuk Teknis Mengenai Akses Informasi Keuangan Untuk Kepentingan Perpajakan

Peraturan Direktur Jenderal Pajak Nomor PER24/PJ/2010 tentang Perubahan Atas PER61/PJ/2009 Tentang Tata Cara Penerapan Persetujuan Penghindaran Pajak Berganda (P3B)

Peraturan Direktur Jenderal Pajak Nomor PER25/PJ/2010 tentang Perubahan Atas PER62/PJ/2009 Tentang Pencegahan Penyalahgunaan Persetujuan Penghindaran Pajak BergandaUndang-Undang Nomor 11 Tahun 2016 Tentang Pengampunan Pajak

Peraturan Direktur Jenderal Pajak Nomor PER59/PJ/2010 Tentang Tata Cara Pelaporan Penerimaan Dividen, Penghitungan Besarnya Pajak Yang Harus Dibayar, Dan Pengkreditan Pajak Sehubungan Dengan Penetapan Saat Diperolehnya Dividen Oleh WP Dalam Negeri Atas Penyertaan Modal Pada Badan Usaha Di Luar Negeri Selain Badan Usaha Yang Menjual Sahamnya Di Bursa Efek

Peraturan Direktur Jenderal Pajak Nomor PER69/PJ/2010 tentang Kesepakatan Harga Transfer (Advance Pricing Agreement)

Peraturan Direktur Jenderal Pajak Nomor PER32/PJ/2011 tentang Perubahan PER43/PJ/2010 tentang Penerapan Prinsip Kewajaran Dan Kelaziman Usaha Dalam Transaksi Antara WP Dengan Pihak Yang Mempunyai Hubungan Istimewa

Peraturan Direktur Jenderal Pajak Nomor PER22/PJ/2013 tentang Pedoman Pemeriksaan Terhadap WP Yang Mempunyai Hubungan Istimewa

\section{Website}

Andreas Adoe. 2014. Base Erosion and Profit Shifting, Apa Pengaruhnya bagi Indonesia. Diakses pada tanggal Maret 22, 2017, melalui http://www.ortax.org/ortax/?mod=issue\&pag e=show\&id $=61$ 
Antaranews. 2016. Menkeu: 2.000 Perusahaan Modal Asing Tidak Bayar Pajak. Diakses pada tanggal Maret 22, 2017, melaui http://www.antaranews.com/berita/551189/ menkeu-2000-perusahaan-modal-asing-tidakbayar-pajak

Canada Revenue Agency. 2013. New Reporting Requirements: Reportable Transactions. Diakses pada tanggal Mei 14, 2017, melalui http://www.craarc.gc.ca/nwsrm/fctshts/2013/m08/fs130830eng.html

Cornell Law School. 26 U.S. Code $\$ 6111$ - Disclosure of Reportable Transactions. Diakses pada tanggal Mei 14, 2017, melalui https://www.law.cornell.edu/uscode/text/26/ 6111

Cornell Law School. 26 U.S. 26 CFR 1.6011-4 Requirement of Statement Disclosing Participation In Certain Transactions By Taxpayers. Diakses pada tanggal Mei 14, 2017, melalui

https://www.law.cornell.edu/cfr/text/26/1.60 11-4\#c_3

Darussalam dan Danny Septriadi. 2009. Tax Avoidance, Tax Planning, Tax Evasion, dan Anti Avoidance Rule. Diakses pada tanggal Maret 22, 2017, Diakses pada tanggal Maret 24, 2017, melalui http://www.ortax.org/ortax/?mod=issue\&pag $\mathrm{e}=$ show $\& \mathrm{id}=36 \& \mathrm{q}=\& \mathrm{~h} / \mathrm{m}=1$

DDTC. 2016. Analisis Perencanaan Pajak: Siapkah Indonesia Menerapkan Mandatory Disclosure Rules. Diakses pada tanggal Maret 22, 2017, melalui

http://news.ddtc.co.id/artikel/9345/analisisperencanaan-pajak-siapkah-indonesiamenerapkan-mandatory-disclosure-rule/
Direktorat Jenderal Pajak. 2017. Membangun Kerjasama Bilateral Perpajakan dengan Otoritas Pajak Inggris. Diakses pada tanggal Maret 22, 2017, melalui http://www.pajak.go.id/content/news/memb angun-kerjasama-bilateral-perpajakandengan-otoritas-pajak-inggris

Direktorat Jenderal Pajak. 2014. Mengenal Penghindaran Pajak, Tax Avoidance. Diakses pada tanggal Maret 24, 2017, melalui http://www.pajak.go.id/content/article/meng enal-penghindaran-pajak-tax-avoidance

Internal Revenue Services. Instructions for Form 8886. Diakses pada tanggal Mei 14, 2017, melalui https://www.irs.gov/instructions/i8886/ch01. html

Internal Revenue Services. Instructions for Form 8918. Diakses pada tanggal Mei 14, 2017, melalui https://www.irs.gov/instructions/i8918/ar01.h tml

Leila Majed. 2016. Implementation in France of The Disclosure of Aggressive Tax Planning Arrangements Under Action 12 Of BEPS. Diakses pada tanggal Maret 22, 2017, melalui Diakses pada tanggal Maret 26, 2017, melalui http://www.abdf.com.br/index.php?option=c om_content\&view=article\&id=2175:implemen tation-in-france-of-the-disclosure-ofaggressive-tax-planning-arrangements-underaction-12-of-beps\&catid=28:artigos-darevista\&/temid $=45$

Taxand. 2008. Portugal Enacts Disclosure Rules on Abusive Planning. Diakses pada tanggal Mei 15, 2017, melalui http://www.taxand.com/taxandstake/news/portugal-enacts-disclosure-rulesabusive-planning

University of Oxford. 2012. Centre for Business Taxation Reports on Tax Avoidance. Diakses pada tanggal Maret 22, 2017, melalui https://www.law.ox.ac.uk/news/2012-12-05centre-business-taxation-reports-taxavoidance 